\title{
Serapan Hara N, P, K dan Pertumbuhan Tanaman Jagung Pada Berbagai Dosis Pupuk Anorganik dan Organik di Tanah Inceptisol
}

\author{
Nutrient (N, P, K) Uptake and Growth of Corn Plants at Various Doses of \\ Inorganic and Organic Fertilizers in Inceptisol Soils
}

\author{
Mulyati*, Baharuddin, AB, Tejowulan R.S \\ Program Ilmu Tanah Fakultas Pertanian Universitas Mataram \\ *Corresponding Author Email: yatimulyati@unram.ac.id
}

Manuscript received: 08-12-2020. Accepted: 25-10-2021

\begin{abstract}
ABSTRAK
Penggunaan pupuk anorganik mempunyai peranan penting dalam meningkatkan pertumbuhan dan produksi tanaman. Tetapi juga menyebabkan timbulnya berbagai permasalahan seperti penurunan bahan organik tanah, kemasaman tanah, degradasi tanah, ketidak-seimbangan hara dan meningkatkan pencemaran lingkungan. Oleh karena itu perlu diimbangi dengan pemberian pupuk organik. Suatu percobaan lapang dilakukan untuk mengkaji pengaruh aplikasi berbagai dosis pupuk anorganik dan organik terhadap serapan hara N, P, K dan pertumbuhan tanaman jagung. Rancangan percobaan yang digunakan adalah rancangan acak kelompok yang ditata secara faktorial yang terdiri atas dua faktor. Faktor pertama adalah dosis pupuk anorganik (A) : 0,150 dan $300 \mathrm{~kg} \mathrm{ha}^{-1}$ phonska dan faktor kedua adalah pupuk organik plus $(\mathrm{P}): 0,10,20$ ton $\mathrm{ha}^{-1}$. Kedua faktor dikombinasikan dan masing-masing kombinasi perlakuan diulang tiga kali. Data yang dipeoleh dianalisis dengan analisis keragaman pada taraf nyata 5\%. Hasil penelitian menunjukkan bahwa tidak interaksi antara pemberian pupuk anorganik dan organik terhadap pertumbuhan dan serapan hara N, P dan K. Namun demikian, aplikasi pupuk anorganik dan organik berpengaruh nyata terhadap semua sifat-sifat agronomis yang diuji kecuali pada tinggi tanaman. Serapan hara N, P dan K juga meningkat secara signifikan akibat pemberian pupuk anorganik dan organik. Keseimbangan aplikasi pupuk anorganik dan organik meningkatkan ketersediaan hara dan juga serapan hara N, P, dan K oleh tanaman jagung.
\end{abstract}

Kata kunci : serapan; hara; pertumbuhan; pupuk; jagung

\begin{abstract}
The use of inorganic fertilizers has an important role in increasing plant growth and production. But it also causes various problems such as decreasing soil organic matter, soil acidity, soil degradation, nutrient imbalance and increasing environmental pollution. Therefore, it needs to be balanced with the provision of organic fertilizers. A field experiment was conducted to study the effect of application of
\end{abstract}


various doses of inorganic and organic fertilizers on $\mathrm{N}, \mathrm{P}, \mathrm{K}$ nutrient uptake and maize plant growth. The experimental design used was a randomized block design arranged in a factorial manner consisting of two factors. The first factor is the dose of inorganic fertilizer (A): 0,150 and $300 \mathrm{~kg}$ ha-1 phonska and the second factor is organic fertilizer plus $(\mathrm{P}): 0,10,20$ tons ha- 1 . The two factors were combined and each treatment combination was repeated three times. The data obtained were analyzed by analysis of variance at the 5\% level of significance. The results showed that there was no interaction between the application of inorganic and organic fertilizers on the growth and nutrient uptake of $\mathrm{N}, \mathrm{P}$ and $\mathrm{K}$. However, the application of inorganic and organic fertilizers had a significant effect on all tested agronomic traits except for plant height. Nutrient uptake of $\mathrm{N}, \mathrm{P}$ and $\mathrm{K}$ also increased significantly due to the application of inorganic and organic fertilizers. The balance of inorganic and organic fertilizer application increases the availability of nutrients as well as the uptake of $\mathrm{N}, \mathrm{P}$, and $\mathrm{K}$ nutrients by maize plants.

Keywords: nutrient; uptake; growth; fertilizer; corn

\section{PENDAHULUAN}

Tanaman jagung (Zea mays L.) merupakan tanaman pangan yang memiliki prospek ekonomi yang cukup potensial. Jagung banyak diminati karena mengandung karbohidrat, protein dan vitamin yang tinggi, kadar lemak rendah, vitamin A dan C yang tinggi mengandung banyak sukrosa, sedikit glukosa, fruktosa, maltosa dan pati. biasa (Rubatzky dan Yamaguchi, 1998). Selain itu, jagung juga berfungsi sebagai bahan baku industri dan pakan ternak. Produktivitas jagung manis secara nasional masih tergolong rendah yaitu 4,81 ton/ha dan belum mencukupi kebutuhan nasional, sehingga diperlukan upaya peningkatan produksi hingga dapat mencukupi kebutuhan nasional mencapai potensi yang mencukupi.

Peningkatan produksi jagung dapat dilakukan melalui pemupukan. Tanaman jagung merupakan tanaman yang membutuhkan unsur hara dalam jumlah yang banyak. Sehingga, umumnya petani menambahkan pupuk anorganik dengan dosis yang tinggi, bahkan mencapai dosis yang tidak rasional. Penggunaan pupuk anoganik terutama N, P, dan K dalam jumlah yang besar dan secara terus-menerus akan mengakibatkan tanah menjadi padat, dan ini sangat mengganggu sistem perkembangan akar. Selain itu, infiltrasi dan penyerapan air terhambat, sehingga akan terjadi akumulasi hara tertentu yang berakibat pada pencemaran lahan dan degradasi tanah, yang pada gilirannya akan menghambat pertumbuhan dan perkembangan tanaman. Dengan demikian, diperlukan upaya yang bijak dalam meningkatkan produksi jagung dengan menerapkan pemupukan secara berimbang, sehingga efisiensi pemupukan dapat tercapai (Made, 2010).

Namun pemupukan pada pertanaman jagung sangat dipengaruhi oleh kondisi tanah dan iklim. Hingga saat ini pemupukan pada tanaman jagung masih diberikan dalam jumlah yang sama. Tujuan penelitian ini adalah untuk mengelola penggunaan pupuk organik dan meningkatkan efisiensi penggunaan pupuk anorganik terutama $\mathrm{N}, \mathrm{P}, \mathrm{K}$, serapannya dan produktivitas jagung. Oleh karena penggunaan pupuk anorganik saja sudah tentu tidak cukup tetapi harus dibarengi dengan penggunaan pupuk organik. Akhir-akhir ini berbagai pupuk organik tersedia di pasaran, tetapi harganya mahal, dan memiliki komposisi yang kurang berimbang terutama untuk memperbaiki sifat fisik akibat pemupukan berat.

Sekaitan dengan hal tersebut, maka diperlukan pemupukan organik plus yang ramah lingkungan, yang dibuat dari bahan baku limbah-limbah pertanian yang ada di sekitar 
petani seperti sisa tanaman dan hewan, yang ditambahkan biochar sebagai pembenah tanah (soil amendment), dan di dalam prosesnya juga melibatkan kegiatan mikrooorganisme tanah seperti EM-4 (Effective microorganism) Dengan demikian dapat diharapkan sifat fisik, kimia dan biologi tanah dapat dipertahankan dan diperbaiki dan produksi jagung dapat ditingkatkan. Biochar atau arang pertanian merupakan bahan pengandung karbon (C) yang tinggi berkisar antara 85-98\%, dihasilkan dari proses pemanasan biomassa bahan organik pada kondisi oksigen terbatas (pyrolysis). Biochar berwarna hitam, ringan, mudah hancur dan selain mengandung $\mathrm{C}$ juga mengandung abu dan senyawea kimia lainnya, sehingga pemanfaatan biochar untuk tanah-tanah pertanian mempunyai pengaruh untuk jangka waktu yang panjang (longterm effect), dan biochar tersusun dari struktur rantai C-aromatik mempunyai luas permukaan yang tinggi per satuan massa dan kepadatan muatan yang tinngi (Lehmann, 2007; Woolf, 2008).

Pemanfaatan biochar ini dapat memperbaikan terhadap sifat fisik: menggemburkan tanah, memperbaiki aerasi dan drainase, meningkatkan ikatan antar partikel, meningkatkan kapasitas menahan air, mencegah erosi dan longsor, dan merevitalisasi daya olah tanah. Fungsi pupuk organik terhadap sifat kimia yaitu meningkatkan kapasitas tukar kation, meningkatkan ketersediaan unsur hara dan meningkatkan proses pelapukan bahan mineral. Adapun terhadap sifat biologi yaitu menjadikan sumber makanan bagi mikroorganisme tanah seperti fungi, bakteri, serta mikroorganisme menguntungkan lainnya, sehingga perkembangannya menjadi lebih cepat (Glaser et al., 2002; Yamamoto et al., 2006). Dengan demikian penelitian tentang Serapan hara N, P, K dan pertumbuhan tanaman jagung pada berbagai dosis pupuk anorganik dan organik di tanah Inceptisol telah dilakukan.

Adapun tujuan dari penelitian ini adalah untuk mengetahui : (1) Pengaruh pemberian pupuk anorganik dan organik plus terhadap perubahan karakteristik tanah ; (2) Pengaruh pemberian pupuk anorganik dan organik plus terhadap serapan hara N, P dan K oleh tanaman jagung ; (3) Pengaruh pupuk anorganik dan organik plus terhadap pertumbuhan dan hasil tanaman jagung. Adapun kegunaan penelitian ini diharapkan dapat bermanfaat bagi pengembangan ilmu dan informasi bagi petani dalam melakukan teknik budidaya tanaman jagung melalui pemanfaatan pupuk organik plus untuk efisiensi penggunaan pupuk anorganik.

\section{METODE}

\section{Rancangan Percobaan}

Metode yang digunakan dalam penelitian ini adalah metode eksperimental dengan percobaan lapangan. Percobaan dilaksanakan di kebun percobaan Fakultas Pertanian Universitas Mataram, Desa Narmada, Kecamatan Narmada, Kabupaten Lombok Barat. Rancangan percobaan yang digunakan adalah Rancangan Acak Kelompok (RAK) faktorial yang terdiri atas dua faktor. Faktor pertama adalah pupuk organik plus $(\mathrm{P})$ yang terdiri atas 3 aras : $\mathrm{P}_{0}$ (Tanpa pupuk organik plus), $\mathrm{P}_{1}\left(10\right.$ ton ha $\left.{ }^{-1}\right), \mathrm{P}_{2}\left(20\right.$ ton ha $\left.\mathrm{h}^{-1}\right)$, dan faktor kedua adalah pupuk anorganik (A) yang terdiri atas 3 aras yaitu $\mathrm{A}_{0}$ (tanpa pupuk anorganik), $\mathrm{A}_{1}$ (150 $\left.\mathrm{kg} \mathrm{ha}^{-1}\right)$ dan $\mathrm{A}_{2}\left(300 \mathrm{~kg} \mathrm{ha}^{-1}\right)$. Sehingga diperoleh 9 kombinasi perlakuan, selanjutnya masingmasing kombinasi perlakuan diulang 3 kali, dan didapat 27 perlakuan. 


\section{Pelaksanaan Percobaan.}

Pelaksanaan percobaan ini diatur dengan tahapan-tahapan sebagai berikut:

1. Penyiapan Lahan. Dilakukan dengan mengolah tanah secara tradisional menggunakan bajak dan cangkul untuk menggemburkan tanah dan meratakan permukaan tanah. Pengolahan tanah dilakukan dengan pengairan selama semalam yang tujuannya agar tanah mudah digemburkan dan juga membersihkan gulma dari sisa pertanaman sebelumnya agar tidak mengganggu pertumbuhan. Selabjutnya dibuat petak percobaan dengan ukuran 260 x $125 \mathrm{~cm}$, jarak antar petak $30 \mathrm{~cm}$ dan jarak antar blok $50 \mathrm{~cm}$.

2. Penanaman Benih. Benih yang digunakan pada percobaan ini adalah benih jagung manis varietas Bonanza F1. Jarak tanam yang digunakan adalah 70x25 cm dan setiap lubang diisi 2 butir biji jagung manis.

3. Pemupukan. Dilakukan sesuai dengan perlakuan, untuk pupuk anorganik selanjutnya dilakukan juga pemupukan susulan dengan urea sebanyak $100 \mathrm{~kg} \mathrm{ha}^{-1}$. Pada umur 35 hari setelah tanam. Pupuk ditugal dengan jarak $5 \mathrm{~cm}$ dari lubang tanam. Sedangkan untuk pupuk organik plus dibaut terlebih dahulu dengan bahan asal pupuk kandang, Biochar dan EM-4 yang difermentasikan terlebih dahulu selama 4 minggu.

Pelaksanaan penelitian lain seperti Pengairan, Penyulaman, Penjarangan, penyiangan dan pembumbunan serta pembenrantasan hama dan penyakit dilakukan sesuai dengan teknik budidaya tanaman jagung manis umumnya yang dilakukan oleh petani di sekitar lokasi penelitian.

\section{Variabel yang Diamati}

Variable pengamatan terdiri atas tanah dan tanaman. Terhadap tanaman dilakukan : Tinggi Tanaman (cm), dan jumlah daun (helai) diamati pada umur 7, 14, 21, 28, 35, 42, 49, 56 dan 63 hari setelah tanam (hst); Panjang Tongkol $(\mathrm{cm})$, Diameter Tongkol $(\mathrm{cm})$ tanpa kelobot; Berat Tongkol; Bobot Brangkasan kering Tanaman (g) dengan cara dioven pada suhu $70{ }^{0} \mathrm{C}$ sampai mencapai berat konstan dan ditimbang (berat kering tanaman dimaksudkan untuk analisis kadar hara N, P dan K pada jaringan tanaman; Berat Tongkol per Petak (kg) dan berat 100 Biji (g).

\section{Panen}

Pemanenan jagung manis dilakukan pada saat tanaman berumur 42 hari setelah tanam yaitu pada fase vegetatif maksimum untuk menghitung serapan hara. Selanjutnya panen untuk fase generatif dilakukan pada saat ujung tongkol telah terisi penuh, warna dari biji jagung manis telah menguning, rambut jagung telah berwarna kecoklatan.

\section{Analisis Data}

Data hasil pengamatan dianalisis dengan menggunakan sidik ragam (ANOVA) pada taraf nyata 5\%, dan untuk perlakuan yang berbeda nyata dilakukan uji lanjut menggunakan uji Beda Nyata Jujur (BNJ) pada taraf yang sama. 


\section{HASIL DAN PEMBAHASAN}

\section{Karakteristik tanah sebelum percobaan}

Tanah merupakan media pertumbuhan tanaman dan sumber utama unsur hara makro dan mikro esensial yang diperlukan oleh tanaman. Sifat fisik, kimia dan biologi tanah merupakan faktor pembatas untuk pertumbuhan tanaman dan dari ketiga faktor pembatas tersebut, sifat kimia tanah yang terkait dengan ketersediaan hara seperti hara $\mathrm{N}, \mathrm{P}$ dan $\mathrm{K}$ merupakan faktor pembatas utama untuk pertumbuhan tanman. Sebelum percobaan dimulai perlu diketahui terlebih dahulu kondisi awal tanah. Table 1. Menunujukkan sifat tanah yang digunakan dalam percobaan ini seperti yang disajikan pada tabel berikut :

Tabel 1. Karakteristik tanah percobaan

\begin{tabular}{lccc}
\hline \multicolumn{1}{c}{ Variable } & Method & Value & Kategori \\
\hline Tektur: Sand (\%) & Sedimentasi & 56.7 & Lempung berpasir \\
Silt (\%) & & 32.67 & \\
Clay (\%) & & 10.66 & \\
pH- $\mathrm{H}_{2} \mathrm{O}$ & pH meter & 5.68 & masam \\
C-Organic $(\%)$ & Walkley \& Black & 1.04 & rendah \\
N-Total $(\%)$ & Kjeldahl & 0.20 & rendah \\
C/N ratio & - & 10.20 & sedang \\
KTK & Ammo-Acetat & 10.28 & rendah \\
P-tersedia (ppm) & Bray I & 21.57 & rendah \\
K-tertukar (ppm) & Morgan Wolf & 42.75 & tinggi \\
\hline
\end{tabular}

Hasil analisis keragaman menunjukkan bahwa tanah yang digunakan dalam percobaan memiliki kesuburan yang rendah, dengsn tekstur lempung berpasir yaitu 56,67\% pasir, $32,67 \%$ debu dan 10,66\% liat. Ketiga komponen tekstur tanah ini sangat berpengaruh terhadap aerasi tanah, pengolahan tanah, infiltrasi, kemampuan tanah memegang air (WHC), penyerapan hara dan aktivitas mikroba. Kemasaman tanah $(\mathrm{pH})$ tanah merupakan parameter kimia penting yang mempengaruhi ketersediaan hara (Brady dan Weil, 2002., pH tanah 5,68, ini menunjukkan $\mathrm{pH}$ tanah asam. Ketersediaan berbagai unsur hara untuk tanaman mempunyai hubungan yang erat dengan pH tanah (Maschner, 2002). Oleh karena itu, penerapan biochar dan penggabungan kotoran gak secara berkala sangat penting untuk perbaikan pH tanah (Gupta, 2004).

Kadar C-organik, kapasitas tukar kation tanah, kadar N-total tanah juga tergolong rendah dan $\mathrm{C}: \mathrm{N}$ rasio tergolong sedanghara $\mathrm{N}$ dan $\mathrm{P}$ rendah kecuali $\mathrm{K}$ berharkat tinggi, serta rendah. kecuali Kalium. Sehingga dengan menggunakan pupuk organik plus yang terbuat dari kotoran sapi, biochar sekam padi dan ditambahkan dengan EM4 yang difermentasi selama 4 minggu dapat diharapkan dapat meningkatkan produktivitas tanah dan meningkatkan pertumbuhan dan hasil jagung. Hasil analisis tanah Inceptisol yang digunakan dalam percobaan ini berasal dari bahan induk volkan tua yang didominasi oleh mineral liat kaolinit (1:1). Tanah ini mempunyai tingkat kesuburan yang rendah dengan faktor pembatas utama sifat-sifat kimia tersebut di atas. Namun demikian, tanah Inceptisols yang berada di lahan kering (Dystropepts) dapat dikembangkan untuk pertanian tanaman pangan, seperti : jagung, kedelai, kacang-kacangan, padi gogo, dan lain-lain (Golsworthy and Fisher, 1992). 


\section{Perubahan Sifat Kimia Tanah Setelah Percobaan}

Pengaruh pupuk anorganik dan organik plus berpengaruh nyata terhadap perubahan $\mathrm{pH}$ dan kapasitas tukar kation (Tabel 2). Aplikasi pupuk anorganik menunjukkan perbedaan yang nyata terhadap $\mathrm{pH}-\mathrm{H}_{2} \mathrm{O}$ dan kapasitas tukar kation (KTK). Dari tabel tersebut nampak bahwa tanpa pemberian pupuk phonska dan pemberian $150 \mathrm{~kg} \mathrm{ha}^{-1}$, menyebabkan $\mathrm{pH}$ tanah meningkat dari 6.42 menjadi 7.21 sedangkan peningkatan berikutnya menjadi $300 \mathrm{~kg} \mathrm{ha}^{-1}$ tidak menunjukkan perbedaan yang nyata. Demikian pula dengan aplikasi pupuk organik plus. Hal ini menunjukkan bahwa peningkatan $\mathrm{pH}$ dan KTK tanah akan berpengaruh terhadap ketersediaan hara di dalam tanah, sementara peningkatan KTK dalam tanah menyebabkan peningkatan retensi hara dan menurangi kehilangan hara karena pelindian, dan pada gilirannya akan meningkatkan kesuburan dan kualitas tanah.

Table 2. Pengaruh pupuk anorganik dan organik plus terhadap $\mathrm{pH}$ dan KTK tanah

\begin{tabular}{ccc}
\hline Perlakuan & pH $\left(\mathbf{H}_{\mathbf{2}} \mathbf{O}\right)$ & KTK $\left(\mathbf{c m o l ~ k g}^{-\mathbf{1}}\right)$ \\
\hline A0 & $6.42 \mathrm{~b}$ & $39.46 \mathrm{~b}$ \\
A1 & $7.21 \mathrm{a}$ & $47.27 \mathrm{a}$ \\
A2 & $7.29 \mathrm{a}$ & $47.16 \mathrm{a}$ \\
HSD (5\%) & 0.20 & 5.8 \\
P0 & $6.57 \mathrm{c}$ & $40.52 \mathrm{~b}$ \\
P1 & $6.80 \mathrm{~b}$ & $46.72 \mathrm{a}$ \\
P2 & $7.06 \mathrm{a}$ & $48.00 \mathrm{a}$ \\
HSD (5\%) & 0.18 & 5.1 \\
\hline
\end{tabular}

Keterangan : Angka-angka yang diikuti oleh huruf yang sama pada kolom yang sama menunjukkan tidak berbeda nyata pada uji lanjut BNJ 5\%.

Bahan organik merupakan kunci kesuburan tanah dan untuk penyediaan unsur hara esensial setelah mengalami proses dekomposisi oleh microorganisme. Bahan organik ini juga dibutuhkan tanaman sebagai sumber energi bagi mikroorganisme yang berasal dari flora dan fauna, suplai hara untuk pertumbuhan tanaman, pengikatan hara dan sumber material yang penting untuk mendaur hara (Haynes and Naidu, 1998). Gambar 1 menunjukkan bahwa aplikasi pupuk anorganik dapat meningkatkan kadar bahan organik secara signifikant. Tanpa pupuk aorganik plus memberikan kontribusi kadar $\mathrm{C}$ organik yang terndah, hal ini berarti bahwa pupuk organik mempunyai kontribusi yang positif terhadap peningkatan kadar $\mathrm{C}$ organik dalam tanah (Gambar 2), sehingga dapat diharapkan dapat meningkatkan productivitas tanah. Hal ini diduga disebabkan oleh adanya komposisi biochar di dalam pupuk organik plus yang kaya akan material organik, dan ini mempunyai arti penting dalam peningkatan kualitas tanah. 


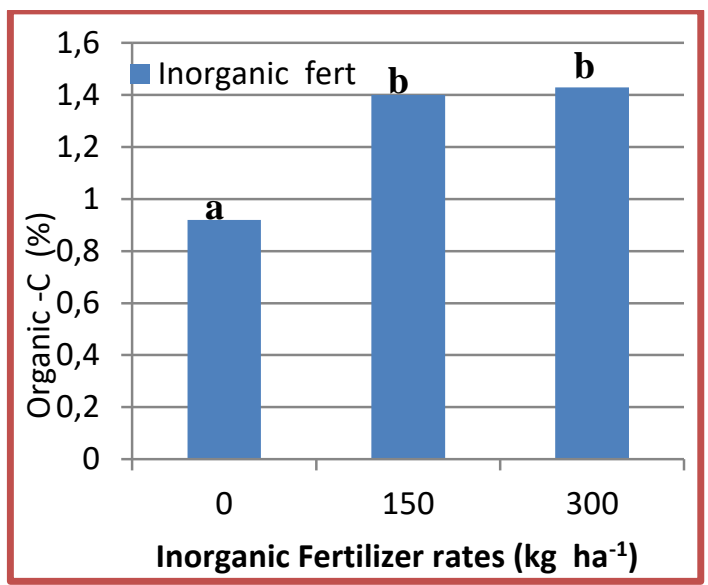

Gambar 1. Pengaruh pupuk anorganik terhadap kadar C-Organik tanah

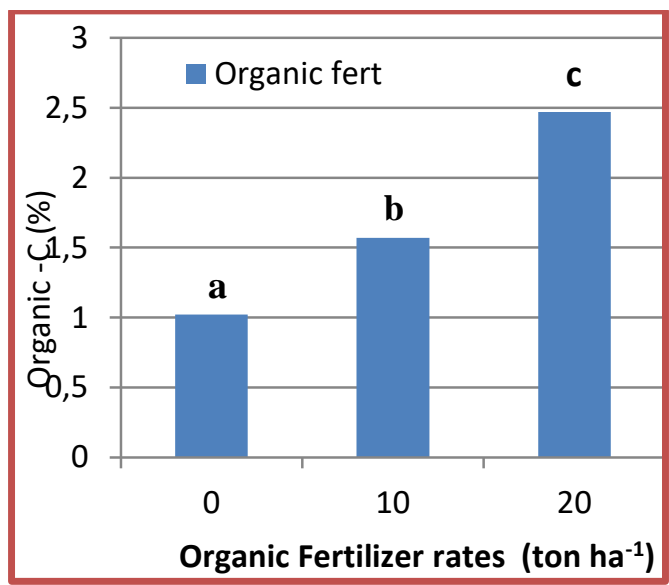

Gambar 2. Pengaruh pupuk organik plus terhadap kadar C-organik tanah

Analisis sidik ragam terhadap unsur hara $\mathrm{N}, \mathrm{P}$ dan $\mathrm{K}$ di dalam tanah menunjukkan perbedaan yang nyata pada aplikasi pupuk anorganik dan organik plus (Tabel 3.), sebagai contoh N-total meningkat dari 0.12 menjadi $0.68 \%$ untuk pupuk anorganik dan untuk pupuk organik plus meningkat dari 0.18 menjadi $0.76 \%$. Peningkatan $\mathrm{N}$-total pada pupuk organik plus lebih tinggi dibandingkan dengan pupuk anorganik. Hal ini diduga disebabkan oleh tingginya kadar bahan organik pada pupuk organik plus yang diaplikasikan ke dalam tanah, dan juga disebabkan oleh pelepasan hara yang terkontrol sesuai dengan saat tanaman membutuhkan. Sebagaimana diketahui bahwa sebagain besar $\mathrm{N}$ dalam tanah berasal dari udara/atmosfer (78\%) dan bahan organik. Sedangkan N dari pupuk anorganik mudah larut, mudah menguap dan terlindi.

Tabel 3. Pengaruh pupuk anorganik dan organik plus pada unsur hara N, P dan K dalam tanah.

\begin{tabular}{cccc}
\hline Perlakuan & \multicolumn{3}{c}{ Kadar hara tanah } \\
\cline { 2 - 4 } & N-Total (\%) & P-tersedia (ppm) & K-tertukar (\%) \\
\hline A0 & $0.12 \mathrm{c}$ & $19.7 \mathrm{c}$ & $0.80 \mathrm{c}$ \\
A1 & $0.53 \mathrm{~b}$ & $25.8 \mathrm{~b}$ & $1.75 \mathrm{~b}$ \\
A2 & $0.68 \mathrm{a}$ & $27.7 \mathrm{a}$ & $2.05 \mathrm{a}$ \\
HSD 5\% & $\mathbf{0 . 0 8}$ & $\mathbf{1 . 2}$ & $\mathbf{0 . 2 3}$ \\
P0 & $0.18 \mathrm{c}$ & $18.3 \mathrm{~b}$ & $0.78 \mathrm{~b}$ \\
P1 & $0.54 \mathrm{~b}$ & $25.6 \mathrm{a}$ & $1.90 \mathrm{a}$ \\
P2 & $0.76 \mathrm{a}$ & $26.5 \mathrm{a}$ & $2.15 \mathrm{a}$ \\
HSD 5\% & $\mathbf{0 . 0 7}$ & $\mathbf{1 . 3}$ & $\mathbf{0 . 5 6}$ \\
\hline
\end{tabular}

Keterangan : Angka-angka yang diikuti oleh huruf yang sama pada kolom yang sama menunjukkan tidak berbeda nyata pada uji lanjut BNJ $5 \%$.

Nitrogen adalah unsur hara makro yang diserap tanaman dalam jumlah yang besar oleh tanaman, namun untuk tanah di daerah tropik, $\mathrm{N}$ menjadi salah satu unsur yang seringkali ditemukan kahat atau defisien untuk peningkatkan produksi tanaman (Maschner, 2002). Ini yang menjadi salah satu penyebab penggunaan pupuk anorganik yang terus meningkat terutama pupuk yang mengandung hara makro seperti phonska yang mengandung unsur hara $\mathrm{N}$, P dan $\mathrm{K}$, sehingga terjadi pengangkutan hara oleh tanaman dari dalam tanah dalam 
jumlah yang tinggi. Pengaruh pemberian pupuk anorganik dan organik plus terhadap serapan hara N, P dan K oleh tanaman jagung disajikan pada Tabel 4. Serapan hara sangat dipengaruhi oleh kondisi hara di dalam tanah, dan tanah sebagai media pertumbuhan tanaman diharapkan mampu mensuplai hara bagi tanaman yang tumbuh di atasnya. Jika suplai hara kurang maka perlu dilakukan

Tabel 4. Serapan hara N, P dan K oleh tanaman jagung akibat aplikasi pupuk anorganik dan organik plus.

\begin{tabular}{lccc}
\hline Perlakuan & \multicolumn{3}{c}{ Serapan Hara $\left(\mathbf{k g ~ h a} \mathbf{~}^{-1}\right)$} \\
\cline { 2 - 4 } & $\mathbf{N}$ & $\mathbf{P}$ & $\mathbf{K}$ \\
\hline $\mathrm{A} 0$ & $76.25^{\mathrm{b}}$ & $9.71^{\mathrm{b}}$ & $10.80^{\mathrm{c}}$ \\
$\mathrm{A} 1$ & $98.35^{\mathrm{a}}$ & $16.38^{\mathrm{a}}$ & $21.75^{\mathrm{b}}$ \\
$\mathrm{A} 2$ & $103.83^{\mathrm{a}}$ & $17.57^{\mathrm{a}}$ & $32.05^{\mathrm{a}}$ \\
$\mathrm{BNJ}$ & 12.84 & 3.91 & 5.11 \\
P0 & $75.12^{\mathrm{b}}$ & $8.32^{\mathrm{b}}$ & $10.78^{\mathrm{c}}$ \\
P1 & $97.56^{\mathrm{a}}$ & $16.56^{\mathrm{a}}$ & $22.90^{\mathrm{b}}$ \\
$\mathrm{P} 2$ & $102.75^{\mathrm{a}}$ & $18.45^{\mathrm{a}}$ & $32.15^{\mathrm{a}}$ \\
$\mathrm{BNJ}_{0.05}$ & 11.76 & 4.13 & 5.87 \\
\hline
\end{tabular}

Keterangan : Angka-angka yang diikuti oleh huruf yang sama pada kolom yang sama menunjukkan tidak berbeda nyata pada uji lanjut BNJ 5\%.

pemupukan,dan sebelum hara diserap oleh bulu-bulu akar, hara yang ditambahkan dalam bentuk pupuk hara akan berubah menjadi ion-ion melalui 3 mekanisme yaitu (1) aliran massa (mass flow); (2) diffuse dan (3) pertukaran kation (cation exchange) yaitu pertukaran antara ion dalam larutan tanah dengan akar (Rosmarkam dan Yuwono, 2002). Jumlah total unsur hara yang diserap oleh tanaman jagung selama pertumbuhannya dapat digunakan sebagai indikator kebutuhan hara tanaman tersebut selama hidupnya.

Dosis pupuk anorganik phonska 15:15:15 berpengaruh nyata terhadap variabel serapan $\mathrm{N}, \mathrm{P}$ dan $\mathrm{K}$ oleh tanaman jagung (Tabel 4.). Uji beda nyata jujur dengan signifikansi 5\% menunjukkan bahwa pada berbagai dosis aplikasi pupuk anorganik dan organik plus berpengaruh nyata terhadap serapan $\mathrm{N}, \mathrm{P}$ dan $\mathrm{K}$. Tanpa pemberian pupuk phonska menghasilkan serapan $\mathrm{N}, \mathrm{P}$ dan $\mathrm{K}$ yang terendah, peningkatan dosis phonska sebanyak 150 $\mathrm{kg} \mathrm{ha}^{-1}$ memberikan pengaruh yang nyata dibandingkan dengan ontrol atau tanpa phonska, namun demikian peningkatan menjadi $300 \mathrm{~kg} \mathrm{ha}^{-1}$ phonska tidak memberikan pengaruh yang nyata untuk serapan $\mathrm{N}, \mathrm{P}$ dan $\mathrm{K}$. Hal ini diduga adanya pelepasan hara dari pupuk organik plus dan dan kontribusinya ke dalam tanah, dan fenomena ini mencermikan adanya efisiensi pemberikan pupuk anorganik dengan adanya pemberian pupuk organik plus, sehingga pemberian pupuk anorganik dapat diturunkan.

\section{Komponen Pertumbuhan dan Hasil Tanaman Jagung}

Pengaruh perlakuan pemberian pupuk anorganik dan organik plus untuk meningkatkan pertumbuhan dan produksi mempunyai peranan penting terutama dengan berkembangnya varietas-varietas unggul yang sangat respon terhadap pemupukan. Gambar 3. menunjukkan bahwa laju pertumbuhan tanaman $\left(\mathrm{cm} \mathrm{minggu}^{-1}\right)$ meningkat seiring dengan peningkatan dosis pupuk anorganik dari tanpa pemberian pupuk phonska menjadi $150 \mathrm{~kg} \mathrm{ha}^{-1}$, meskipun dengan 
peningkatan dosis yang lebih tinggi terjadi peningkatan laju pertumbuhan tinggi tanaman tetapi peningkatannya tidak menunjukkan perbedaan yang nyata. Hal yang sama juga terjadi pada aplikasi dengan pupuk organik plus (Gambar 4). Peningkatan pupuk organik plus dari 10 menjadi 20 ton ha $^{-1}$ juga tidak memberi pengaruh yang nyata. Hasil yang diperoleh sejalan dengan hasil penelitian Sutanto (2002) yang menunjukkan bahawa pemberian bahan organik tergantung pada jenis tanahnya. Pada jenis tanah Andisol 16 ton $\mathrm{ha}^{-1}$ bahan organik sudah memberikan hasil yang tertinggi di antara perlakuannya tetapi pada tanah Ultisol membutuhkan bahan organik yang lebih tinggi mencapai 25 ton ha- ${ }^{1}$.

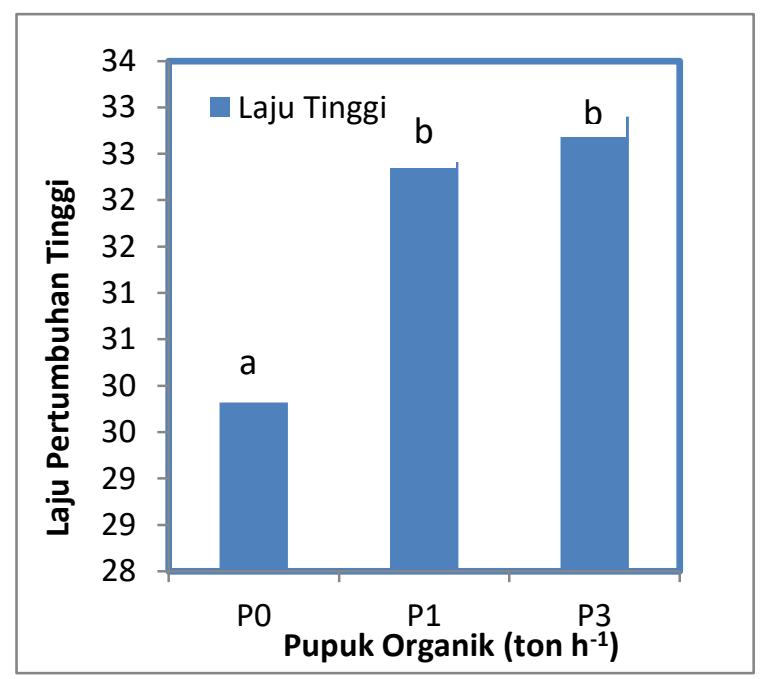

Gambar 3. Pengaruh pupuk anorganik terhadap laju pertambahan tinggi tanaman $\left(\mathrm{cm} \mathrm{minggu}^{-1}\right)$

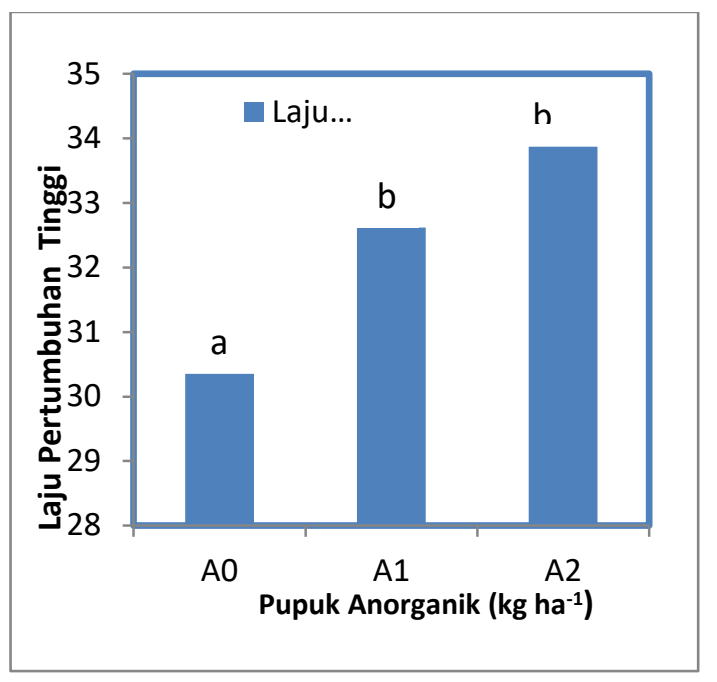

Gambar 4. Pengaruh pupuk organik terhadap laju pertambahan tinggi tanaman $\left(\mathrm{cm} \mathrm{minggu}^{-1}\right)$

Pada Tabel 5. menunjukkan bahwa laju pertambahan daun (helai minggu ${ }^{-1}$ ) tertinggi dicapai pada perlakuan pemberian pupuk anorganik sebanyak $300 \mathrm{~kg} \mathrm{ha}^{-1}$ dan pupuk organik plus sebanyak 20 ton $\mathrm{ha}^{-1}$ (Tabel 5.) Sedangkan pada peningkatan dosis selanjutnya untuk pupuk anorganik dan organik plus masing-masing tidak memberikan pengaruh yang signifikan.

Table 5. Tanggapan pertumbuhan dan hasil tanaman jagung terhadap pemberian pupuk anorganik dan organik plus

\begin{tabular}{ccccc}
\hline Perlakuan & \multicolumn{4}{c}{ Variabel Pengamatan } \\
\cline { 2 - 5 } & $\begin{array}{c}\text { Laju ptbh daun } \\
\left(\text { helai minggu }^{-1}\right)\end{array}$ & $\begin{array}{c}\text { Bobot kering } \\
\left(\mathrm{g} \mathrm{tan}^{-1}\right)\end{array}$ & $\begin{array}{c}\text { Berat tongkol } \\
\left(\mathrm{g} \mathrm{tan}^{-1}\right)\end{array}$ & Berat 100 biji (g) \\
\hline A0 & $19.7 \mathrm{~b}$ & $38.3 \mathrm{c}$ & $186.7 \mathrm{c}$ & $7.81 \mathrm{~b}$ \\
A1 & $22.8 \mathrm{a}$ & $52.3 \mathrm{~b}$ & $245.4 \mathrm{~b}$ & $13.32 \mathrm{a}$ \\
A2 & $23.5 \mathrm{a}$ & $57.8 \mathrm{a}$ & $267.7 \mathrm{a}$ & $18.56 \mathrm{a}$ \\
HSD 5\% & $\mathbf{1 . 2}$ & $\mathbf{1 0 . 2 3}$ & $\mathbf{1 5 . 1 2}$ & $\mathbf{0 . 5}$ \\
\hline P0 & $18.8 \mathrm{~b}$ & $37.8 \mathrm{c}$ & 198.5 & $7.42 \mathrm{~b}$ \\
P1 & $24.8 \mathrm{a}$ & $53.5 \mathrm{~b}$ & 225.3 & $16.74 \mathrm{a}$ \\
P2 & $25.5 \mathrm{a}$ & $56.5 \mathrm{a}$ & 257.6 & $18.17 \mathrm{a}$ \\
HSD 5\% & $\mathbf{1 . 7 0}$ & $\mathbf{1 0 . 8 5}$ & $\mathbf{1 4 . 8 5}$ & $\mathbf{0 . 9 0}$ \\
\hline
\end{tabular}

Keterangan : Angka-angka yang diikuti oleh huruf yang sama pada kolom yang sama menunjukkan tidak berbeda nyata pada uji lanjut BNJ 5\%. 
Pertumbuhan tanaman merupakan pertambahan berat atau panjang karena adanya pembesaran sel. Tabel 5. menunjukkan bahwa ada perbedaan yang nyata antara pemberian pupuk anorganik dan organik, Laju pertambahan daun tertinggi dicapai pada dosis tertinggi baik untuk pupuk anorganik maupun yang organik. Perlakuan dengan phonska terbaik diperoleh pada pemberian $150 \mathrm{~kg} \mathrm{ha}^{-1}$ dan ini tidak berbeda nyata dengan pemberian $300 \mathrm{~kg}$ $\mathrm{ha}^{-1}$. Demikian pula tidak ada beda nyata antara pemberian 10 ton ha ${ }^{-1}$ dan 20 ton ha ${ }^{-1}$ pupuk organik plus. Bobot brangkasan kering tanaman tertinggi diperoleh pada pemberian $300 \mathrm{~kg} \mathrm{ha}^{-}$ ${ }^{1}$ phonska dan 20 ton ha $^{-1}$ pupuk organik plus.

Pemberian pupuk phonska meningkatkan bobot tongkol dan 100 biji kering jagung. Pemupukan phonska 15-15-15 sebanyak $150 \mathrm{~kg} \mathrm{ha}^{-1}$ nyata meningkatkan bobot tongkol kering dan 100 biji jagung. Bobot pipilan kering biji jagung tertinggi dicapai pada pemupukan $300 \mathrm{~kg} \mathrm{ha}^{-1}$ phonska 15-15-15 dan nyata dibandingkan dengan dosis $150 \mathrm{~kg} / \mathrm{ha}$ (Tabel 5.). Peningkatan dosis pupuk phonska 15-15-15 menjadi $300 \mathrm{~kg} \mathrm{ha}^{-1}$ tidak meningkatkan bobot 100 biji kering jagung pipilan jika dibandingkan dengan dosis $300 \mathrm{~kg}$ 1ha. Dengan demikian dapat dikatakan dosis optimum phonska 15-15-15 untuk tanaman jagung adalah $150 \mathrm{~kg} \mathrm{ha}^{-1}+250 \mathrm{~kg}$ urea/ ha dengan bobot pipilan kering biji jagung 6,05 t/ha. Pupuk NPK majemuk tidak dapat digunakan secara mandiri, harus ditambah pupuk-pupuk NPK tunggal dan majemuk 15-15-15 baik digunakan sebagai sumber hara N, P, dan K dalam pemupukan berimbang tanaman jagung.

Kebutuhan pupuk $\mathrm{N}$ untuk tanaman jagung selain dari NPK harus ditambah $\mathrm{N}$ dari pupuk urea. Kontribusi hara $\mathrm{N}$ untuk meningkatkan hasil jagung lebih banyak dibandingkan hara $\mathrm{P}_{2} \mathrm{O}_{5}$ dan $\mathrm{K}_{2} \mathrm{O}$. Berdasarkan hubungan dosis pupuk NPK dengan bobot 100 biji kering jagung, dan analisis usahatani, dosis optimum pupuk NPK 15-15-15 adalah $150 \mathrm{~kg} \mathrm{ha}^{-1}$ ditambah 20 ton ha ${ }^{-1}$ Pemberian pupuk NPK 15-15-15 nyata meningkatkan serapan hara N, P, dan K, serapan hara lebih tinggi melalui biji jagung daripada brangkasan.

\section{Kesimpulan}

\section{KESIMPULAN DAN SARAN}

Berdasarkan hasil dan analisis hasil serta terbatas pada ruang lingkup penelitian ini dapat disimpulkan bahwa Pemberian pupuk organik berperan untuk meningkatkan produktivitas tanah $\mathrm{pH}$ tanah, bahan organik, dan ketersediaan $\mathrm{N}$, P dan $\mathrm{K}$ tanah, Pemberian pupuk anorganik dan organik meningkatkan serapan hara $\mathrm{N}, \mathrm{P}$ dan $\mathrm{K}$, serta pertumbuhan jagung. Kombinasi pemberian pupuk anorganik dan organik dapat mengefisiensikan penggunaan pupuk anorganik baik untuk pertumbuhan maupun serapan hara $\mathrm{N}, \mathrm{P}$ dan $\mathrm{K}$ oleh tanaman jagung. Pemberian pupuk anorganik sebanyak $200 \mathrm{~kg} \mathrm{ha-}{ }^{1}$ sudah dapat memenuhi kebutuhan hara untuk pertumbuhan dan hasil tanaman jagung manis.

\section{Saran}

Dengan demikian dapat disarankan untuk melakukan penelitian lebih lanjut tentang kombinasi pemberian pupuk anorganik dan organik yang paling tepat untuk pertumbuhan tanaman serta pengaruh dari residu pupuk baik organik plus maupun anorganik dalam mendukung pertanian berkelanjutan (sustainable agriculture).

\section{Ucapan Terima Kasih}


Tim peneliti menyampaikan terima kasih kepada bapak Rektor, Ketua Lembaga Penelitian dan Pengabdian kepada masyarakat dan Dekan Fakultas Pertanian Universitas Mataram atas dukungan fasilitas dan dana yang telah diberikan.

\section{DAFTAR PUSTAKA}

Aleel, K.G. 2008. Phosphate Accumulation in Plant. Signaling. Plant Physio, 148:3-5.

Badan Pusat Statistik. 2015. Luas panen, Produktivitas dan Produksi Jagung Manis Menurut Provinsi. http://www.bps.go.id , 28/11/2008.

Brady, N, C., Weil, R. R. 2002. The nature and Properties of Soils. 13th edition. Pearson Education, New Jersey.

Ganorkar, R. P. and Chinchmalatpure, P. G. 2013. Physicochemical Assessment of Soil in Rajura Bazar in Amravati District of Maharastra (India). International Journal of Chemical, Environmental and Pharmaceutical Research : 4(2\&3), 46-49.

Gardner, F. P. Pearce, R. B. dan Mitchell R. L. 1991. Fisiologi Tanaman Budidaya. UI. Press.

Glaser, B., Lehmann, J. Zech, W. 2002. Ameliorating Physical dan Chemical Properties of Highly Wethered Soils in the Tropics with Charcoal. A Review. Biol. Fertil Soils. 35 : 219-230.

Goldsworthy, P. R. dan Fisher, N. M. 1992. Fisiologi Tanaman Budidaya Tropik. Gadjah Mada University Press. Yogyakarta.

Gupta, P. K. 2004. Soil, Plant, Water and Fertilizer Analysis. Shyam Printing.

Hardjowigeno, S. 2003. Ilmu Tanah. Akademika Presindo. Jakarta.

Haynes, R. J. and Naidu, R. 1998. Influence of Lime, Fertilizer and Organic Manure on Soil Organic Matter Application and Soil Physical Condition. Nutr.Cycl. Agroecosyst. 51: 123-137. Kumar, D. Jhariya, N. A. 2013. Nutritional, Medicinal and Economical Importance of Corn: A Mini Review. Research Journal of Pharmaceutical Sciences, 2, $7-$ 8. Press. London. UK.

Lehmann, J. 2007. Bio-energy in the Black. Front Ecology Environment 5: 381-387.

Lehmann, J. and Joseph, S. 2009. Biochar for Environmental Management. Earthscan. UK.

Laird, D.A. 2008. The Charcoal vision: a Win-Win-Win Scenario for Simultaneously Producing Bioenergy, Permanently Sequestering Carbon, While Improving Soil and Water Quality. Agron. J. 100:178-181.

Liu, E., Changrong, Y., Xurong, M., Wenqing, H., So, H.B., Linping, D., Qin, L., Shuang, L., Tinglu, F. 2010. Longterm Effect of Chemical Fertilizer, Straw, and and Manure on Soil Chemical and Biological Properties in Northwest China, Geoderma 150: 173-180.

Made. 2010. Respons Berbagai Populasi Tanaman Jagung Manis (Zea mays saccharata Sturt.) Terhadap Pemberian Pupuk Urea. J Agroland. 17(2):138-143.

Marchner, H. 2002. Mineral Nutrition on Higher Plant. Academi Press. 2nd edition. Harcourt Jovanovich Publisher. London.

Mirwandono, E., Sitepu, M. Wahyuni, T. H. Hasnudi, N., Siregar, G. A. W. and Sembiring, I. 2018. Nutrition Quality Test of Fermented Waste Vegetables by Bioactivator Local Microorganisms (MOL) and Effective Microorganism (EM4). International Conference on Agriculture, Environment, and Food security. IOP Conf. Series: Earth and Environmental Science 122: (2018) 012127. 
Mulyati dan Lolita, E.S. 2006. Pupuk dan Pemupukan. UPT Universitas Mataram Press. Mataram.

Purwono dan R. Hartono. 2008. Bertanam Jagung Unggul. Penebar Swadaya. Jakarta.

Rubatzky, V.E., and Yamaguchi M.1995. Sayuran Dunia : Prinsip, Produksi, dan Gizi. Jilid ke-1. Herison C, Penerjemah. Bandung (ID): ITB Pr. Terjemahan dari: World Vegetables: Principles, Production, and Nutritive Values.

Rubatzky, V.E., and Yamaguchi M. 1998. Sayuran Dunia: Prinsip, Produksi, dan Gizi. Herison C, Penerjemah. Bandung (ED): ITB Pr. Terjemahan dari: World Vegetables: Principles, Production, and Nutritive Values.

Salisbury, B.F. dan Ross W.C. 1995. Fisiologi Tumbuhan. Alih Bahasa oleh Diah R. Lukmana dan Sumaryono, ITB Bandung. 343 Hal.

Sandhu, K. S., Singh, N., and Malhi, N. S. 2007. Some Properties of Corn Grains and Their Flours I: Physicochemical, Functional and Chapati-making Properties of Flours. Food Chemistry, 101: 938-946.

Sitompul, S. M., dan B. Guritno. 1995. Analisa Pertumbuhan Tanaman. Gadjah Mada.

Sutanto, R. 2002. Penerapan Pertanian Organik: Pemasyarakatan dan pengembangannya. Kanisius Publisher. Yogyakarta. ISBN 9792101. 219h,

Tracy, W. F. 1994. Sweet Corn. In: A. R. Halleuer (Ed.) Specialty Corns. USA: CRC Press Inc.

Warisno. 2007. Jagung Hibrida. Kanisius. Yogyakarta. 43-56 h.

Woolf, D. 2008. Biochar as a Soil Amendment : A Review of the Environmental Implication. http://orgprints.org/13268/1/Biochar_as_a_Soil_Amendment_a Review pdf. Retrieved 2 October 2008.

Yamato, M., Okimori, Y., Wibowo, I.F., Anshioro, S. and Ogawa, M. 2006. Effects of Application of Charred Bark of Acacia Mangium on the Yiled of Maize, Cowpea and Peanut, and Soil Chemical Properties in South Sumatra, Indonesia. Soil Sci. Plant Nutr., 52:489-495. 